Redefinition of the Position of Women in Osonye Tess Onwueme's Play 


\title{
Redefinition of the Position of Women in Osonye Tess Onwueme's Play the Reign of Wazobia
}

\author{
Gloria Eme Worugji \\ Department of Theatre Arts, University of Calabar - Nigeria \\ Email:ajieleeme@yahoo.com
}

\begin{abstract}
Tess Onwueme is a Nigerian female playwright who is devoted to changing the position of women in her society, as her plays depicts. The Reign of Wazobia is one of such plays. The play portrays the story of women around a female character 'Wazobia' who rebels against the customs of her people. She articulates concern over the undignified position of women in her society; a situation which most modern female scholars view as an act of injustice meted to women in most African societies. The female protagonist "Wazobia" in the play informs the basis of our analysis. She is endowed with certain character traits that do not only portray her as deviant or non conformist in this male dominated society, but also, as a voice to the voiceless in such societies. At the end of the play, even the traditional ridden female characters, became conscious of their low status in the society and joins in the crusade against all forms of discriminations experienced by women in the society. This paper argues for the need to educate and to recognize the presence, strength and the contributions of women in societal growth. This is necessary if the women must be free to participate in nation building, beginning from the rural level; this is because, a recognition of the women's ability is a panacea for a positive development in any society and as popularly known, two different heads are better than two of the same kind and teamwork doubles the success.
\end{abstract}

\section{INTRODUCTION}

The marginalization of women manifest in nearly all aspects of life in the patriarchal society. This is the singular factor that prompted the then, Iraq president of blessed memory, Saddam Hussein to make the statement:

We want our whole country liberated ... It's impossible for the Iraq people to realize all the objectives of the revolution without correcting the position of the woman in the society ... we cannot conceive of a society in which the woman does occupy the right position befitting the human being which the revolution seeks to create and draw upon(12). 
This statement is in tune with the focus of this paper and the play under study. The woman must be positioned properly in any progressive society. To sum up Hussein's affirmation above, women aught to move along the same growth level as the society.

As Ama Ata Aido points out, "the position of women in Africa has been no less ridiculous"(17). So that Hussein's statement is not only peculiar to the Iraq society or to the western world; the situation is rather worst in most African patriarchal society, where women are relegated to the background.

In order to correct this negative image, Onwueme projects a dominant female character in the role of Wazobia in the play, to let the society know that African women are equal to any tasks, if given the opportunity. We have some positive cases of female ministers in Nigeria who performed excellently and better than the men who were in such position during their national assignments. Thus; Sigmund Freud once states: "The great question that has never been answered and which I have not yet been able to answer despite my thirty years of research into the feminine soul is, what does a woman want"?(110). Freud may be asking this question out of unacceptability of the women's move for liberation, just as some male scholars would say, women are liberated, what do they want again?

One might rephrase Freud's question by asking what is the feminist movement all about?. The answer to the question is provided by Yammer Kaazer, a woman activist from Egypt, who in 1983, during a national convention on women's rights summarized what the feminist movements spread all over the globe want as: "equal duties and responsibilities, unconditional opportunities along political, economic, social, cultural and technological lines" (3).

In an earlier reaction to the demands by feminist movements for equal rights with men, which Kaazer affirms above, Randall Golberg in 1964 asserts that "nature had made men and women different and thus the law must accommodate itself to these feminists who are not making claim to physical equality with men. This point has been stressed by Debora Dobie and some other women activists at various times. Their claim simply is that physical differences are not valid reasons for the discriminatory treatment women experience. While blaming the secondary role women are playing in society on the socialization process, Dobie argues:

some of the most powerful men in the world are physically smaller than the average woman ... neither Henry Ford nor John D. Rocke Feller were muscular men ... for many years the late Howard Hughes was an ailing reduce, ruled one of the world's financial empires. There are no physical characteristics that would have made a woman less effective in any of these roles (The New woman (68).

This is true as the image of Wazobia in The Reign of Wazobia reveals. Also countering the belief held by some men notably is Malik Mubarak who contends that women are intellectually superior to some men and Nawal ElSaadawi in The Hidden Face of Eve, points out by adding that history shows 


\section{Gloria Eme Worugji}

that "women started to exercise the powers of their mind before men, they were the first to embark on the quest for knowledge; the first goddess of knowledge she says, was Eve, later to be succeeded by the pharoanic Isis" (211). So women are not fickle minded as believed by some male scholars.

A sacred area like religion is not even spared by the feminist in their fight for emancipation. El - Saadawi in The Hidden Face of Eve discussed this. Another woman activist, Tola Adeniyi during a national workshop organized by the national commission for Women in 1990 strongly urged women to free themselves from any bondage or restrictions imposed on them by religion. In the midst of these voices, two major factors have been identified and that is, education and industrialization by Buck Grisroll and John Damshakaal as responsible for the increased demand for equality with men by women especially in the late $20^{\text {th }} \mathrm{c}$. These two analysts are of the opinion that with increase in the educational opportunities, more women are now becoming aware of their rights, privileges and responsibilities in society. Damshakaal buttresses this point further that "No one can be more than the sum of his education: "if one's knowledge is limited and exposure narrow, it is bound to reflect in his perception of himself and his role in the society ..." (6). Thus, education is pivotal for the emancipation of women. Therefore, one's limitation in knowledge, definitely affect all aspect of one's living.

Zulu Sofola has an added view on the lateness of women in the writing scene. She states "women are more burdened with humdrum of daily life than men. And therefore it takes extra effort on the part of the females to write..." (60). The dominant thematic interest in all the works of these African female writers are what we now commonly refer to as the "female question". Their works reflect the predicament of the African women, their potentials, desires and quest for a society where men and women will live as equal members of the human race. Unlike most of the male writers, the aim of women writers is essentially to fight for the liberation of the African women from all unjust and oppressive conditions in the society and from the female point of view.

The treatment of women in most male authored works, (where women are mostly relegated to the background) is different from that of the women writers (in which women are given prominent position) this is exemplified in The Reign of Wazobia among others. The reason is obvious as Barbara love aptly put it:

In the works of most African men, we are often invincible. In the works of African women, we have found our faces and voices, found images to sustain us. These works reflect for us the struggle and despair, the lack and loss in our lives ... (6).

This explains Emelia Oko's remark that men writers lack the skill to understand female characters which makes it mandatory for women writers to create new destiny for women (68)", through their writings. These men are the types dominated by patriarchal concept about the woman. African men and those from the Nigerian society in particular should be willing to accept 
women as partners in progress as this will make for a faster growth of the society.

\section{Analysis of the Play}

Tess Onwueme continues with the story on projecting the image of women as she redefines their position in her play The Reign of Wazobia. Iyase's statement during a crucial meeting exemplifies this male discriminatory behaviour on women, when it comes to community affairs. The scene below reveals this:

Iyase: (Standing) then king, if we must deliberate on such serious matters, women and the youths must be sent away.

Wazobia: I do not see any reason why women...must be kept away from matters of state concern. Matters of state affect them much as they affect chiefs and princes.

Idehen: I support what my fellow chief, Iyase, has said. Serious matters of state concern are too heavy for the brittle heads of women and children (p.27).

A particular picture is created in our minds through the above dialogue and that is, that, male chauvinism exist in the Anioma kingdom of Eastern Nigeria, where the play is set. Exclusion of women from serious state matters is silencing strategy employed by men to keep women away from power. The central character of the play is Wazobia, an educated young woman, who was elected the regent of Anioma kingdom following the death of king Ogiso; having been chosen by the priests for the next three seasons - in accordance with what tradition stipulates; pending the enthronement of another male ruler. Wazobia makes it explicit to all and sundry that the centre-piece of her administration is the re-definition of the position of women. Thus, she reveals her intention to her people when she makes the following statement as she summons them to her palace:

The king has gathered you to make this pronouncement, that whatever you call yourself, you are. Everyone of you, first and foremost are HUMAN BEINGS with potentials waiting to be actualized for the benefit of this kingdom. .. Henceforth, we all, man woman, shall have equal rights ... none is a slave to another. Man and woman are decreed as partners in progress (p.29).

Wazobia's pronouncements represent an attack on the age-long discrimination against women. The views of the men about women in the kingdom is that women are not their equals, and that they are also not intelligent enough to deliberate on issues of state matters as men. This has resulted into women being victimized in various ways. For instance, tradition denies them access to the leadership throne as well as representation in the chief's council. They can only serve as regents or chair warmers (as they are sarcastically called) for three seasons whenever a male king dies. Also, women do not have right to inheritance and succession to family property. The play counters this view as Wazobia states"... henceforth women shall 


\section{Gloria Eme Worugji}

have equal rights to inheritance, and ... in matters of land and property" (p. $34)$.

Again, participation in rituals is classified as very strict and very important sacred culture strictly reserved for the males. This statement has been ascertained by Cynthia Anderson that it is not unusual for instance, to find a woman of ninety years for being a female, strictly forbidden to watch a ritual performance while her grandson of six years for being a male, is at liberty not only to watch enthusiastically, but also to participate actively" (18). This is the lot of the females in a typical African patriarchal society, the males are speared this discrimination.

It is also a custom in the kingdom that whenever a man passes on, his wife must undergo certain funeral rituals which include, dancing naked in the market place. Wazobia questions and condemns this aspect of tradition when she asked; "Why, may I ask, must widows be subjected to the torment of incessant funeral rites that men are free of under similar situations ... "? (p.21). However, if she dies in the course of performing these rituals, she is held responsible for the death of her husband while the man is spared this trauma if the reverse is the case. This is a double standard the tradition creates and a traditional humiliation on women.

Wazobia a representative of the women's voice, believes in change while Omu beliefs in the tradition which must be obeyed (Omu is the oldest woman and the head of the women's wing in the kingdom, it is believed she custodies the tradition). This scene gives a summary of the argument.

Ornu: Tradition passed down to us from the time when the world's eyes were still close. Tradition handed down from generation to generation must not be changed.

Wazobia: The face of the sun changes, so does the face of the clock.

Omu: I know not clock: Clock know not me" (p.22).

The female agenda is to determine what happens to them and not allow crocked hands of the tradition to move them. Wazobia warns the women, "whether Omu believes in change or not, there must be change for the Ilaa women of Anioma, in Delta state .... You seek to keep the clock stand still, Omu, ... gravity must take its toll. I will not be intimidated. For now, that is food enough, chew it" (p.23). In other words, change must prevail fixity of tradition and time.

Nevertheless, one would have expected all the women in the kingdom to give a full backing to Wazobia the king's revolutionary policy since it will mark an end to their domination and emasculation by men. But the contrary is the case. Omu, the oldest woman in the land, referred to as "king of women" is absolutely satisfied with the second fiddle role women play and makes it, clear to Wazobia, without mincing words, that she will not be a party to the dearth of tradition. Omu's stance shows the extent to which some women have internalized the notion that they are inferior to men. However, as a result of Wazobia's persuasive argument and explanation, she later relinquishes her conservative posture and gives full support to Wazobia's women liberation policy. 
The female power and authority in most cases is usually undermined and so, not regarded by the men in the society. For instance, the king's power affords refuge for the weak and victimized in most African societies; any one who run to them for protection is expressly protected traditionally, but, the reverse is the case here because of the sex of the one on the throne; for instance, a woman runs to the king for refuge. "My king I am in your hands. Save me" (p.24). This plea and traditional ethical code is ignored as the man replies to the woman, "you may run into a mouse hole. These hands must teach you today that they were not made of decaying plantain stem ... " (p. 23). This statement by the man, whose wife runs to the king for refuge, generates anger on the king, because the king's authority over his subject is being challenged. Wazobia (the King) makes no hesitation at questioning the man's impetus over his action. "Do you realize that what you are doing now is against tradition? Tradition forbids you to touch anyone who has protection of another...more so your king? Is it that men in this part make traditions for others to bear them? "The man replies" Tradition? And that is why a woman... a mere woman that I paid to get with my own hard earned money should challenge me in my house? Does she think I carry these balls between my thighs for nothing?

Wazobia: And that is an answer to your king?

Man: It is no matter for the king and subject, but a matter for man and woman. The gods of our land ordained that a man must own a wife to bear him children ...Wazobia (interrupting): And did your gods also ordained that you must turn these women to slaves? That their tongues must be slashed for daring to see with their eyes? (p. 25).

This dialogue reveals the true state of the woman in a patriarchal society. Intimidation and victimization are her daily lot, in such society. The traditional rules and regulations are to be obeyed by only the women and not by every member of the society which includes the men. Any woman who aspires beyond the traditionally stipulated role and sometimes even within such traditional role, like in the case of Wazobia, is seen as being deviant, in behaviour.

Such women are battered mentally and otherwise. Otherwise King Wazobia asked a simple question that demands a simple answer, rather than the man answering the question, the issue of wife and child bearing became paramount to him. This reminds us of Christie Achebe's statement that "as a mother, the Nigerian woman's eternally designed primary role is procreation, the making of babies in her womb ... she is expected clearly and not ambiguously to have as many ... children as possible ..." $\{4\}$. This, simply suggest that, the African woman's traditionally prescribed role, places her as a machine for making babies. Perhaps, this is what gives the man in the play the impetus, to stand his grounds not minding his disrespect for tradition (i.e. disobeying the king).

Also, the issue of bride price and phallus is raised in same dialogue. In other words, phallus, symbol of power appeals to phallic. This symbol rather gives the man power over his wife as he gives no concrete reason for 


\section{Gloria Eme Worugji}

his action against his wife. The dialogue rather present the woman as man's property. In view of the above, the social expectations of women limit them in the society as Wazobia reminds the men "you complain that their hands are weak when you forbid them to use the hand... you condemn their feet as frailty but shudder when they want to stand firm on the soil ... " (28). All these are signs that the men rule the African world, they decide for the society. But, the modern woman is not ready to continue with this outdated culture, they insist on change against unprogressive traditional laws.

The scene below throws more light to this fact.

Wazobia: I know often when men are united. When they have a common enemy and that is WOMAN." (29) ... for centuries men have ruled and misruled us... the vandalism you saw a moment ago is only a minor testimony of their eras of misrule. Time is blind like rain, it knows no king. Time has come for you to hear some home-truths. That we have kept quiet and observed your excesses ... these long seasons does not mean we lack the words. Nor do we lack the power to curb male excesses. Time has come for us to point the new directions of our rulership. We must begin with the man who pursued his wife, straight into the palace. Where is the woman abused? Stand, woman? Let the world see how your body has been turned into an accident car for panel-beating ... will that brute stand?stand before this gathering for all to see! (The man adamant, does not stand but the eyes of the crowd have already identified him. Brief silence):You are the man. Why do you remain seated when the King commands? Man:You called for the brute. I am no brute

Then what are you? What name do you on earth call yourself when you pound a grown woman like fufu in a mortar (pp.30-32).

In this scene, we see weapons of intimidation often employed towards gender silencing. Wazobia in this scene, reverses the position of women against man's excesses. Wife battering is totally condemned, although, the society does not see any wrong in that. To them, the payment of bride price is a tangible reason for brutalizing their wives as earlier seen; another instance, among others is that of Wazobia's mother Kaenebi who Anehe states "What is news is that Kaenebi, a woman...that her husband pounded ... like fufu... will now be a Queen-mother while we are still alive" (p.14). This is a male feeling about the woman. It also border on jealousy and a desire not to have Kaenebi as the Queen mother if possible. This reveals that some men too, can be jealous of the progressing woman.

The climax of Wazobia's radicalism is witnessed in the play when she refuses to steps down from power after the expiration of her regency. But to the male chauvinists in the kingdom, who are already highly infuriated by the insubordination she has instilled in women, she can only remain in power, over their dead bodies. Under the leadership of lyase and ldehen the two men that nurse the ambition of wearing the crown of Anioma kingdom, they meet in the palace square to map out plans on how to depose Wazobia.

In the words of Iyase: "we have all been witness to the excesses of the one called king. ... Wazobia, the new disease that plagues us. WA-ZO-BIA, 
the new wine that intoxicates ... No matter what happens, women are women ... that we may keep our balance, this new tail or wing by women must be crippled ... we are the head, women cannot rule us. (p.55-56). Iyase's speech that "Women cannot rule us" is reminiscent of Sheik Abubakar Gumi's controversial statement in 1987 - a highly revered Islamic Scholar in Nigeria that; "I do not hope to see a woman rule me while I am alive"(p.7).

This statement sparked off bitter reactions from many Nigerian female scholars. Nevertheless, the final outcome of the men's deliberations is to present a calabash and a steaming pot of herbs to Wazobia. This is the traditional method of issuing a vote of no confidence to a king, and its implication is for the king to either go on self exile or commit suicide. The dialogue below throws more light to this.

lyase: (To Anehe): Whose turn is it to cook for your king today?

Anehe: Well, that is another problem. Since Wazobia ascended the throne, most traditions have been turned upside down. Wives no longer take turns to cook and compete for their husband's tongue and stomach. Wazobj.a insists that we all cook and share together, reducing us all to the same level.

lyase: Don't let that bother you, my sweet one king reign only for a season. Wazobia's reign is even for a shorter season. Let her sow that we may reap. ...

lyase: $\quad .$. The throne is only a foot away from me as a second in command. I know I will get there ... that is why you must help to speed up Wazobia's exit.

lyase: If only you can cook this potion. Wazobia will be no more.

Anehe: (Accepting the plant): But Wazobia and I never get along well.She knows that I resent her.

Iyase: Try, by all means.

Anehe: I know what I will do. I will go through Wa.

Iyase:Be careful. You know your fellow women easily betray you. (p.180)

In other words, men see women as unreliable and a people who cannot keep secret.

Anehe: No, Wa is different ... with her and this plant as enzyme, our plans will speed up. Wazobia may fall sooner than we expect ... we must argue for her deposition.

Anehe: And if she refuses?

Iyase: A simple matter. The people's WILL, will prevail. The people will present Wazobia with steaming herbs in a pot when the people make such demands it is a vote of no confidence on the king. It is a subtle piece of advice for such a king to disappear into the evil forest. He will either proceed on self exile or commit suicide. Either way, Wazobia will receive a hot gift from the people (pp.40-50).

However, the attempt by the enraged men to depose Wazobia through this process was successfully resisted by the women of the kingdom mobilized by Omu, not only to fight for the woman who has raised their status in the society, but also to protect their newly acquired rights. The reaction of these women could be likened to Akomaye Oko's remark that " ... authority is a 


\section{Gloria Eme Worugji}

responsibility that should not be abused, once it is abused, the person in whom this authority is vested loses the right to the obedience the authority commands" (66). It is this authority that is naturally delegated to men through patriarchal order, which by the current trend is abused; so that, the abuse of vested authority, accounts for the emergence of female empowerment, in recent works of art.

\section{CONCLUSION:}

In concluding this work, one would not be wrong to state that, the resistance from the men against the reign of Wazobia, is a rejection and a resistance of the female presence, at the helm of affairs, in the society. Whereas, to empower women is to build a nation and to share the tedious task men are saddled with. Men and women are to compliment each other equally in the socio- political and economic activities of the nation. In view of this, Enejere Emeka opines that "political education enlightens the populace and mobilizes them while, awakening them for the attainment of a just and politically conscious society, where people's rights are respected and not trampled upon" (51).

In view of this, the relegation of women is a disadvantage to any nation. Their undermined input is also a deficit to the people's economy and sociopolitical development. Therefore, the move for the elevation of women's status as this play reveals, is not a revolutionary of the patriarchal order, but, an understanding of the dynamic change in the society to do away with stunted traditions and patriarchal attitudes which inhibits the women member of such society from functioning adequately. To this end Ada A. Mere remarks that:

Contemporary families must be helped to adopt a socialization process that opposes the downgrading, devaluing and exploitation of the female member of the family and encourages a socialization process and activities that brings out all creative potentials of its members, male and female alike" (9).

These and many more of such issues are raised in the play. Finally, the play has empowered the women in the African society in general, and the Nigerian society, with emphasis on the Anioma kingdom, to rise to their challenge and prove to the world that they are not only good leaders, but also, good visioners. The play did not only release women from their societal circumscribed position; but urges them to contribute ideas to social and national issues, and to educate the female child on self realization and her contribution towards national development. This also means that, the interacting of two minds of opposite sex will build, and amend the economic and socio-political crisis/structure of a nation, rather than fighting, struggling or one group permanently intimidating the other over what may be termed "gender war of power over powerlessness". 


\section{WORKS CITED}

Achebe, Christie. "Continuities changes: Women's Rote in Nigeria Society". Presence Africane, 120, 4th Quarterly, 1981, pp. 1-10.

Adeniyi, Tola. The untapped potentials of the Nigerian women" A Paper presented during a workshop organized by the National commission for women in Owerri December 11, 1990.

Anderson, Cynthia. "The Africarl woman" Third World Voice. Massachussetts, May, 1998.

Barber, Hanna. The New Image of Women in Iraq. New York: Harcourt Brace, 1979.

Damshakaal, John. "Women in Power Manifests" Nigerian Newsweek: Lagos: May 23, 1998.

Dobie, Deborah. The New Woman Battimore: Williams and wiilkings 1980

El-Sadawi, Nawal. The Hidden Face of Eve. London: Zed Press, 1980.

Enejere, Emeka. "Women and political education" Nigerian women and the challenges of our time. Ed. Dora Ebi Chizea and Juliet Njeka. Lagos: Malthouse press, 1991.

Golbery, Randall. Women and Law Reforms in America. New York: saint Martins, 1964

Kaazer, Yammer. "Women and Cont:emporary Society" A paper presented at the National Convention on Women's Rights in Egypt; 1985.

Kellison, Rose. Woman power. New York: Russell and Ressel 11, 1978.

Love, Babara. "Images of African American Women". African Commentary: 1998.

Mere, Ada. "The Family as the pivot of Igbo Traditional Education" Igbo Traditional Education Ahia Ajoku Lecture, 1987.

Oko, Akomaye. The Tragic Paradox. Ibadan: Kraft Books, Lagos, 1991.

Onwueme, O. Tess. The Reign of Wazobia. Ibadan: Web Books, Oluseyi Press, 1992. 